\title{
SZERHASZNÁLAT ÉS FELÉPÜLÉS - AZ ÉLMÉNY ÉS IDENTITÁS KAPCSOLATÁNAK VIZSGÁLATA AZ INTERPRETATÍV FENOMENOLÓGIAI ANALÍZISSEL
}

\author{
KASSAI SZILVIA ${ }^{1,2}$ - PINTÉR JUDIT NÓRA ${ }^{3}$ - RÁCZ JÓZSEF ${ }^{2,4}$ \\ ${ }^{1}$ ELTE PPK Pszichológiai Doktori Iskola \\ ${ }^{2}$ ELTE PPK Pszichológiai Intézet, Pszichológiai Tanácsadás Tanszék \\ ${ }^{3}$ SZTE BTK Pszichológia Intézet, Személyiség- Klinikai- és Egészségpszichológia Tanszék \\ ${ }^{4}$ SE Egészségtudományi Kar, Addiktológiai Tanszék \\ E-mail: kassai.szilvia@ppk.elte.hu
}

\begin{abstract}
Tanulmányunk célja annak bemutatása, hogyan alkalmazható az interpretatív fenomenológiai analízis (IPA) módszere, amely kifejezetten az élmény és identitás vizsgálatára kifejlesztett kvalitatív pszichológiai kutatási eszköz a szerhasználat és felépülés vizsgálatára. Az IPA módszere elsôsorban az egészségpszichológia területéról származik, és a legtöbb kutatás továbbra is ezen a területen jelenik meg, mert a módszerrel kiválóan vizsgálhatók olyan tapasztalatok, amelyek befolyásolják az egyén mindennapi életét és azt, ahogyan észleli az identitását. Ilyen tapasztalat lehet a betegség tapasztalat, valamint a függôség, felépülés tapasztalat is. Tanulmányunk során bemutatjuk, hogyan folyik az IPA-kutatás menete, és az identitással kapcsolatos tapasztalatok feltárása, valamint miért fontos az élmény és identitás kapcsolatának vizsgálata a függôség és felépülés során. Végül bemutatjuk korábbi IPA-kutatások és saját kutatásunk tapasztalatait.
\end{abstract}

Kulcsszavak: interpretatív fenomenológiai analizis, élmény, identitás, szerhasználat, felépülés 


\section{BEVEZETÉS}

Az interpretatív fenomenológiai analízis (IPA) egyre gyakrabban alkalmazott kvalitatív kutatási módszer a pszichológiában. Korábbi tanulmányunk során (Rácz, Kassai, Pintér, 2016) beszámoltunk az IPA módszertanáról, alkalmazási területeirôl és a módszertannal végzett kutatási tapasztalatainkról. Valamint további tanulmányok során bemutattuk az IPA gyakorlati alkalmazásának menetét, eloonyeit és a módszerrel végzett kutatásaink eredményeit; addiktológiai területen dolgozó tapasztalati szakértôk identitásalakulásának vizsgálatából származó eredményeket (Kassai, Pintér és Rácz, 2015), a hanghallás (skizofrén tünet) élményének vizsgálata során felfedezett eredményeket (Kassai, Kiss, Pintér és Rácz, 2016), valamint a szintetikus kannabinoid használattal kapcsolatos élmény- és identitásalakulás mintázatait (Kassai, Pintér és Rácz, 2016; Pintér, Kassai és Rácz, 2016). Jelen tanulmány során a kutatásaink eredményeinek illusztrálására bemutatunk egy-egy fớtémát, amellyel azt kívánjuk illusztrálni, hogyan alkalmazható ez a kvalitatív módszer az élmény és identitás vizsgálatára egy olyan speciális területen, mint a szerhasználat, szenvedélybetegség és felépülés.

\section{IPA}

Az IPA módszertanának alapjai a fenomenológiához és a hermeneutikához kapcsolódnak. A fenomenológia középpontjában az egyes szám elsô személyú tapasztalat áll, azt vizsgálja, hogyan észleli az egyén a világot, a tárgyakat és önmagát, hogyan emlékezik a múltjára, hogyan éli meg saját érzelmeit, személyes azonosságát (Ullman és Olay, 2011). A fenomenológiát fémjelzô husserli felszólítás: „vissza magukhoz a dolgokhoz”, arra utal, hogy a módszer túllép a megismerés külsô-belsô hagyományos különbségtevésén, és abból indul ki, hogy az emberi tudat és tárgya össze van kötve egymással, tehát a dolgok nem önmagukban azok, amik, hanem jelentésüket és értelmüket az adja, hogy az egyén számára hogyan jelennek meg (Zahavi, 2003).

Az IPA hermeneutikai elkötelezettséggel a beszámolókban meghúzódó jelentés értelmezésére és azonosítására törekszik. A hermeneutika jeles képviselôi, Heidegger és Gadamer szerint a megértés, magának az emberi létnek a létmódja. A megismerés során bizonyos tapasztalatokhoz alapvetôen nem lehet standarizált eljárásokkal hozzáférni, ehhez járul hozzá a Gadamer által továbbfejlesztett „hermenutikai kör” koncepciója, amelynek alaptétele, hogy a szöveg egésze csak a részei révén ragadható meg, viszont az egyes részek értelme attól az egésztôl függ, amelybe azok bele vannak ágyazva. Az értelmezés folyamata így egy sajátos körmozgással írható le: az újabb információ, feltárult értelem összefüggések alapján az előzó belátásaink is új értelmet nyernek (Gadamer, 1960). A fenomenológia és hermeneutika módszerének alkalmazása nem újkeletû a pszichológiában (lásd Szummer, 1993ab; 2011; Narancsik és Szummer, 2013), azonban az IPA módszerének alkalmazása nem igényli a fenomenológiai hagyomány mély ismeretét, viszont néhány fenomenológiai és hermeneutikai fogalommal érdemes tisztában lennie a kutatónak, amikor elkezd az IPA módszerével kutatni (az IPA két fontos elméleti alapjairól bóvebben; Rácz, Pintér és Kassai, 2017). A filozófiai 
alapokból származó „megértés”, „megismerés” tehát egyfajta párbeszéd az értelmezó és az értelmezett között, amely érzékeny és dinamikus folyamat az IPA-kutatás során lényegi fontosságú (Rácz és mtsai, 2016).

Az IPA módszertana az egészségpszichológia vizsgálati területérôl származik, és a legtöbb IPA-tanulmány továbbra is ezen a területen jelenik meg (Smith, 2011). Ennek oka, hogy az IPA elsôsorban olyan tapasztalatokat vizsgál, amelyek fontosak, jelentôségteljesek az egyén számára, amelyek hatással lehetnek a mindennapi életre és az identitásra (Smith, Flowers és Larkin, 2009). Ilyen tapasztalat lehet a krónikus betegség tapasztalata (Smith, 2006), a függôség, szenvedélybetegség (pl. Shinebourne és Smith, 2009) és felépülés (pl. Rodriguez és Smith, 2014) tapasztalata. Hiányoznak a szakirodalomból azok a kutatások, amelyek azt vizsgálják, milyen hatással van a betegség, függôség, az egyén mindennapi életére, és saját magáról alkotott képére, amely a kezelés, felépülés során fontos területek lehetnek. Az IPA-kutatások ezt a hiányt kívánják betölteni (Smith és mtsai, 2009).

\section{AZ IPA MINT AZ ÉLMÉNY ÉS IDENTITÁS VIZSGÁLATI ESZKÖZE}

Egy IPA-kutatás során a vizsgálat célja annak feltárása, hogyan értelmez a vizsgálatban részt vevố személy egy számára fontos tapasztalatot, így a vizsgálat szerves része, hogyan látja magát az adott helyzetben, hogyan észleli az identitását (Smith és mtsai, 2009). Már a kutatás tervezésekor, a kutatási kérdés megfogalmazásakor ügyelni kell arra, hogy a vizsgálati személy identitást érintô tapasztalata meg tudjon jelenni az adatfelvétel során (Pietkiewicz és Smith, 2014; Smith és Osborn, 2007). Mivel az IPA-adatfelvétel módszere a félig strukturált vagy strukturálatlan interjú (Smith és mtsai, 2009), az interjú során megjelenhetnek olyan leíró részek, ahol az interjúalany ezt részletesen is kifejti, valamint erre vonatkozó külön kérdések is megfogalmazhatók az interjú során, pl. Hogyan látta magát a betegség megjelenése elôtt? Hogyan látta magát a betegség alatt? Hogyan látja magát a betegség után/gyógyulás, felépülés során (Smith és Osborn, 2007)?

Az IPA-vizsgálat tárgya multidimenzionális, dinamikus, kontextusfüggô, szubjektív és relatíve új vizsgálati területet jelöl, ezért az értelemadás és identitásészlelés folyamatának feltárása fontos (Osborn és Smith, 2006). Ezt támogatja az IPA-elemzés menete is, amely az említett hermeneutikai kör koncepcióját alkalmazza. Az elemzés során a kutató idiográfiás módszerrel az interjúalany által leírt tapasztalat minden rétegének, például az identitásra utaló részek aprólékos feltárására törekszik. Elôfordulhat, hogy az interjúalany az interjú során több alkalommal is beszél arról, hogyan látja önmagát, ezeket a kutató az elemzés során összegyújti. Az így kibontakozó témákat beazonosítja és fötémákba rendezi, amelyek összeillesztve gyakran jelölnek folyamatot (Smith és mtsai, 2009). Az identitásra vonatkozó tapasztalat a legtöbb IPA-kutatásban és publikációban külön kibontakozó témaként vagy fốtémaként megjelenik. 


\section{AZ IDENTITÁS ÉS ÉLMÉNY VIZSGÁLATÁNAK FONTOSSÁGA A SZERHASZNÁLAT ÉS A FELÉPÜLÉS SORÁN}

James (1890/1981) identitás modellje elméleti keretként használható annak megértésére, miért fontos az identitás vizsgálata a szerhasználat, függóség és felépülés során. James szelf-koncepciója szerint az én pillanatról pillanatra keletkezik, a testi érzések és az azzal kapcsolatosan felmerülố gondolatok alapján. A pszichoaktív szerhasználat befolyásolja, fokozza a testi észlelést, amely új gondolatokat, új élményeket eredményez. Ezek az új gondolatok vagy értelemadások minôségüknek, újszerüségüknek és egyedülállóságuknak köszönhetôen egy új énhez kezdenek tartozni, amelyek megragadják az átélô figyelmét. Azáltal, hogy az egyén kifejezi az érzéseit, azok jelentését és kiválasztja azt, hogyan gondolkodik róluk, létrehozza önmagát, amely a választás lehetôségét is magában foglalja. Ez az elméleti keret segítséget nyújthat olyan segítố beszélgetések alkalmával, amikor egy szerhasználó számára problémát jelent érzéseinek és kábítószer élménnyel kapcsolatos tapasztalatainak kifejezése (Gray, 2005). Az IPA-módszertan esetében fontosnak tartjuk megemlíteni Ricoeur (1991) narratív identitás elméletét, amely szerint az egyén folyamatosan változik, mégis önmaga marad. Nem véletlen, hogy a szenvedélybetegeket segító anonim önsegítố csoportok az identitáson végzett munkát és az élettörténeti narratíva újraszerkesztésének fontosságát hangsúlyozzák és használják a felépülés során. A felépüléshez szükséges a szerhasználói élmény újraértelemzése, átkeretezése, és ezzel együtt az identitás újraalkotása a stigma eltávolítása (Hill és Leeming, 2014), valamint a szerhasználat elleni éberség fenntartása érdekében (Shinebourne és Smith, 2011).

A szerhasználat és a felépülés alatt történô identitásváltozással kapcsolatos elsô jelentôs kvalitatív eredmények narratív pszichológiai kutatásokból származnak. Ezek alapján a szerhasználat alatti élményszervezôdés az identitásalakulással párhuzamba hozható (McIntosh és McKeganey, 2001). Kezdetben a szerhasználat különleges, pozitív élményt jelent, olyan pozitív identitást ad, amivel könnyen tud azonosulni a szer használója. Késôbb, amikor a drogélmény több negatívummal jár, mint amennyi pozitív élményt ad, a szer használója egyre inkább negatívnak és hamisnak éli meg azt az identitást, amit a használat elején pozitívnak élt meg (McIntosh és McKeganey, 2001). A narratív vizsgálatok az identitásváltozás mozgatórugóinak a fordulópontokat tartják, amelyek jellemzóen az élettörténeti narratíva mélypontjai. A narratíva mélypontig történô ereszkedô majd emelkedô jellege az Anonim Alkoholisták irodalmából ismert (Hänninen és Koski-Jännes, 1999; Koski-Jännes, 1998). A mélypont tapasztalata az identitás újragondolását, az élettörténeti narratíva átszerkesztését facilitálja. Ilyenkor alakulhat ki a „nem szerhasználó, de függő” speciális identitás (McIntosh és McKeganey, 2001).

Bár az IPA-kutatások vizsgálati egységei is narratívák (Smith és mtsai, 2009), az aprólékos elemzés részleteiben rá tud mutatni az identitás fent bemutatott folyamatára, így gyakran egy IPA-vizsgálat a szerhasználattól a felépülésig tartó folyamat egy részletét emeli ki és mutatja be. Az IPA-módszertan használatának elônye tehát abban az eszközrendszerben rejlik, amellyel lehetôvé válik egy folyamat kisebb egységeinek feltárása (pl. milyen az a pozitív identitás, amelyet a szerhasználó a használat elején észlel; hogyan értelmezi az egyén a mélypont tapasztalatát; hogyan alakul a függó és fel- 
épülő identitás?), vagy éppen egy beszámoló kisebb egységeinek folyamatba ágyazása (pl. szintetikus kannabinoid használók identitás élményeinek beleágyazása a felépülési folyamatba). A következőkben röviden bemutatjuk, milyen tapasztalatokat jelenítenek meg az IPA-val végzett vizsgálatok a pszichoaktív szerhasználattal és felépüléssel kapcsolatban, valamint bemutatjuk szintetikus kannabinoid használókkal készült saját kutatásunkat.

\section{Identitásalakulás a pszichoaktív szerhasználat során}

Pszichoaktív szerhasználók vagy felépülô pszichoaktív szerhasználók körében végzett IPA-vizsgálatok tapasztalatai alapján a használat kezdetekor gyakran alakul ki pozitív használói identitás. Ennek oka lehet az identitáshiány miatti üresség betöltésére, önmeghatározásra tett kísérlet (Larkin és Griffiths, 2002; Baross, 2012), vagy egy olyan én elôhívásának eszköze, amelyet józan állapotban el kell nyomni (Shinebourne és Smith, 2009). A „szerhasználó én” tehát kezdetben egy pozitívnak észlelt identitás, amely mindig különbözik a „józan” éntôl. Ez a különbség akkor válik jelentôssé, amikor a szerhasználat egyre több negatív élménnyel jár, és elveszik a „szerhasználó én” feletti kontroll (lásd Shinebourne és Smith, 2009 által bemutatott alkoholbeteg nó identitásváltozása). A mélypont tapasztalata az az esemény, ahol szükséges az identitás újraalkotása. Az önsegítô csoport és szociális visszajelzések segítségével kialakult „függô” identitás esetében a személy már nem a szer használójaként definiálja magát, hanem úgy, mint függôt (Larkin és Griffiths, 2002). Ez szükséges a szerhasználat élményeinek és harcainak megértéséhez és az éberség fenntartásához (Rodriguez és Smith, 2014), mert a szerhasználat kísértése is állandó (Shinebourne és Smith, 2011). Így tehát a felépülés sem végeredmény, hanem sokszor élethosszig tartó folyamat (Laudet, 2007), ezért is fontos, hogy a felépülés az identitás részévé váljon. Ezzel a terápiában és az önsegítô csoportban foglalkoznak, a felépüló és függô identitásokra, mint kettôs, párhuzamos identitásra történố utalással, amely egyfajta távolságtartást jelent a szerhasználó identitástól (Hill és Leeming, 2014; Larkin és Griffiths, 2002).

\section{Szintetikus kannabinoid használók élményszervezôdése és identitásészlelése}

Az utóbbi években megjelenô új pszichoaktív szerek gyors terjedése, a hatásukban megfigyelhetô sajátosságok, a hatások intenzitása miatt, a hatások kialakulásának gyorsasága miatt a terápia sok esetben nehézségekbe ütközik (Kassai, Pintér és Rácz, 2016). Szintetikus kannabinoid (Magyarországon az egyik legelterjedtebb új pszichoaktív szer, továbbiakban: SZK) használókkal végzett IPA-kutatásunk során a használók élményeit és identitásészlelését vizsgáltuk az IPA-módszerrel ${ }^{1}$. Jelen tanulmány során a téma érdekességét az adja, hogy a SZK-használók identitással kapcsolatos élményeit a pszichoaktív szerhasználat és felépülés élményszervezôdésének fentebb részletezett folyamatával hasonlítottuk össze, arra keresve a választ, hogyan valósulhat meg a

\footnotetext{
${ }^{1}$ A kutatás eredményeirôl bôvebben: Kassai, Pintér és Rácz, 2016; Pintér, Kassai és Rácz, 2016.
} 
1. táblázat. Az interjúalanyok jellemzői (Pintér és mtsai, 2016, 317)

\begin{tabular}{l|l|c|c}
\hline Név & Kor & Legmagasabb iskolai végzettség & SZKT használat ideje \\
\hline Ricsi & 27 & Szakmunkásképzó & 2 év \\
\hline Attila & 20 & Nyolc általános & 3,5 év \\
\hline Zsolt & 23 & Érettségi & 6 év \\
\hline Levente & 22 & Nyolc általános & 6,5 év \\
\hline Jerob & 20 & Nyolc általános & 2,5 év \\
\hline Szilveszter & 21 & Nyolc általános & 2 év \\
\hline
\end{tabular}

SZK-használók felépülése, hogyan alakulhat ez a pszichoaktív szerhasználatból történô felépüléséhez képest, amelyre az addiktológiai kezelörendszer be van rendezkedve.

A vizsgálatban részt vevố SZK-használók (demográfiai adatait az 1. táblázat tartalmazza) a drog kiszámíthatatlan hatásáról és a gyorsan pozitívból negatívba forduló élményekról számoltak be. Néhány használat után a drogélmény negatív lett, azonban a függôség gyorsan kialakult, és a súlyos elvonási tünetek megjelenése ellen sûrúbben fogyasztották a drogot. A résztvevôk beszámolója alapján a drog lerombolta ôket fizikailag és mentálisan is. A droghasználat sokkal több negatív hatással járt, mint pozitívval, ennek ellenére mégis folytatták annak fogyasztását. Ezt a résztvevook úgy értelmezték, hogy a drog átalakította ôket, egyfajta „átváltozatott én” alakult ki, amely felett elvesztették a kontrollt, úgy érezték, hogy a szer irányítja ôket, többször utaltak úgy a droghatás alatti önmagukra, mintha nem is ók lennének, eközben az énjük teljesen leépült. A következô fôtéma bemutatásával szeretnénk illusztrálni, hogyan észlelték a kutatás résztvevői az identitásukat.

\section{Fôtéma: az „átváltoztatott én” és a „szerhasználó én”}

Az „átváltoztatott én” itt a szerhasználat következménye, azonban különválik a „szerhasználó éntôl”. Az én a SZKT erôs mentális befolyására „változik át”, mely én-idegen, paranoid és kontrollálhatatlan élményékkel jár, ez ellen a szerhasználattal védekeznek: "féltem attól, hogyha nem veretek be, akkor elöjön az az agresszívabb énem" (Jerob). Tehát a „szerhasználó én” jelent védelmet az idegen, „átváltoztatott énnel” szemben. Az én átmenetileg negatív befolyás alatt áll, és kiszolgáltatott a SZKT „irányító” hatásával szemben. A SZKT (ahogyan ez látható volt) megszemélyesító bemutatása felmentést ad a használónak, ahogyan a beszámolókban is megjelennek a nem ágens kifejezések; a psziché és a test függôsége (mint az „átváltoztatott én” részei) leválnak az énrôl: „kellett, a szervezetem követelte” (Attila); „a pszichém követeli” (Jerob). Tehát a függóség élményei is az „átváltoztatott énhez” kapcsolódnak.

Az interjúalanyok (akik az interjú idôpontjában egy ideje már nem használják a szert) a beszámolók alapján a szerhasználatukra és a függóség tapasztalatára úgy tekintenek vissza, mint egy elmúlt állapotra, lezajlott folyamatra, melynek idején negatív befolyás alatt álltak, azonban a szerhasználat abbahagyásával már nem észlelik az „átváltoztatott ént" sem. 
„Úgyhogy nagyon nehéz volt igazából így ebból kijönni.” „Nem azt mondom, hogy, amikor narkóztam, akkor rossz ember voltam, csak, én nem is tudom, hogy hogy csinálhatok ilyet.” „Ezeket a dolgokat próbálom úgy hanyagolni” (Ricsi) (Pintér és mtsai, 2016, 320-321).

Összehasonlítva az SZK-használók énészlelését a pszichoaktív szerhasználók felépülési folyamatával, a pozitív identitásélmények hiányban nem alakul ki a „szerhasználó én”. A szerhasználat hatásaként megjelenô „átváltoztatott én” nem épül be az identitásba, miközben az énjük teljesen leépül. Hiányzik a mélypont tapasztalata, amely elômozdítaná a függố és felépüló identitás kialakulását. Az SZK-használók élményeit vizsgálva a traumát átélôk élményeihez hasonlítanak az „énvesztést” bemutató sokszor töredezett narratívák. A kutatás eredményei alapján tehát a SZK-használók kezelése során nagyobb hangsúlyt kell fektetni az élményeik narratívákba foglalására és az identitáson végzett munkára (Pintér és mtsai, 2016).

\section{ADDIKTOLÓGIAI TERÜLETEN DOLGOZÓ SAJÁTÉLMÉNYÚ SEGÍTŐK - FELÉPÜLÔ ÉS SEGÍTŐ IDENTITÁS}

Egy korábbi IPA-kutatásunk eredményeit is fontosnak tartjuk idekapcsolni, amelynek tapasztalatai alapján a szerhasználat élményének vizsgálata nem csupán a felépülés során lehet fontos, hanem egy olyan felépüléssel párhuzamos identitás megjelenésekor is, mint a saját élményú segító identitás. Az említett kutatás során addiktológiai területen dolgozó felépülô segítôket vizsgáltunk (Kassai, Pintér és Rácz, 2015), amelynek célja annak felderítése volt, hogyan alakul a felépülő identitás olyan személyek esetében, akik saját élményú segítóként dolgoznak.

Bár a vizsgálat fókusza a felépülés és segítés élményének vizsgálata volt, élettörténet-interjút készítettünk a résztvevoókkel (az interjúalanyok jellemzőit a 2. táblázat tartalmazza), amelybe a függóség élményei is beletartoztak. A segítésre való nyitottság már a felépülés elején megjelent a résztvevôknél, de hivatásos segítôk csak pár év múlva lehettek, amikorra a szerhasználatból származó élményeiket fel tudták dolgozni, felépülő identitásukban meg tudtak erôsödni. A segítô identitás tehát már a felépülés elején megjelent, csak késóbb került elôtérbe. Ezzel együtt nem váltotta le a felépülô identitást, ez a kettô párhuzamosan, sốt egymást kiegészítve múködik a felépülô segítôk esetében. A következô footéma bemutatásával szeretnénk illusztrálni, hogyan észlelik a résztvevôk ezt felképülô és segítô identitást.

\section{A felépülō segítő és a „segitô én”}

A „felépülô segítô” címszó alá azokat a megfogalmazásokat soroljuk, amelyek explicit módon tartalmazzák a segítók felépülési munkáját. A legtöbben megfogalmazták, hogy a felépülés folyamatos munka és egyben tanulási folyamat, ami élethosszig tart, és amit a segítô magán végez a kliensekkel együtt. A munka és a tanulás nem különül el, mindkét kifejezést hasonló értelemben használják ebben a kontextusban. A felépülés az önismeret folyamatos fejlesztése. 
2. táblázat. Az interjúalanyok jellemzói (Kassai és mtsai, 2015, 376)

\begin{tabular}{|c|c|c|c|c|c|c|c|}
\hline & Nem & Életkor & $\begin{array}{l}\text { Iskolai } \\
\text { végzettség }\end{array}$ & $\begin{array}{l}\text { Felépülés során, } \\
\text { segítés céljából } \\
\text { végzett képzés }\end{array}$ & $\begin{array}{c}\text { Szer- } \\
\text { használat } \\
\text { hossza } \\
(\mathrm{min}) \\
\end{array}$ & $\begin{array}{c}\text { Felépülés } \\
\text { ideje } \\
(\text { min })\end{array}$ & $\begin{array}{c}\text { Tapasztalati } \\
\text { segítôként } \\
\text { dolgozik } \\
(\mathrm{min}) \\
\end{array}$ \\
\hline 1 Sindy & Nô & 35 & $\begin{array}{l}\text { Egyetemi } \\
\text { diploma }\end{array}$ & Szociális munka & 4 év & kb. 12 éve & 10 éve \\
\hline 2 Zsolt & Férfi & 47 & $\begin{array}{l}\text { Felsôfokú } \\
\text { szakképzés }\end{array}$ & \begin{tabular}{|l|} 
Színház \\
terapeuta, \\
Szociálterápiás \\
szerepjáték \\
\end{tabular} & 22 év & kb. 8 éve & 6 éve \\
\hline 3 Peti & Férfi & 41 & Érettségi & - & 15 év & kb. 12 éve & 9 éve \\
\hline 4 Zénó & Férfi & 38 & \begin{tabular}{|l}
$\begin{array}{l}\text { Fôiskolai } \\
\text { diploma }\end{array}$ \\
\end{tabular} & Szociális munka & 6 év & kb. 16 éve & 13 éve \\
\hline 5 Feri & Férfi & 51 & $\begin{array}{l}\text { Egyetemi } \\
\text { diploma }\end{array}$ & Szociális munka & 5 év & kb. 10 éve & 1 éve \\
\hline 6 Balázs & Férfi & 26 & Érettségi & - & 3 év & kb. 4 éve & 1 éve \\
\hline
\end{tabular}

A „felépülő én” az interjúalanyok esetében az életük egy olyan szakasza, melyben a múltat újraértékelik, a szerhasználat okait, eseményeit feldolgozzák, ekkor általában az addig nem lévő „önismeretük” is kialakul. Ez az életszakasz gyakran egybeesik a rehabilitációs intézetben (a „terápián”) töltött idôvel. A „segító én” vagy már jelen lévô, vagy késôbb kibontakozó személyiségtartalom, mely az adás örömével, a személyes értékesség többszörös megélésével jár. A „segító én” megjelenése nem a „felépülő én” eltûnése, a kettô együtt van jelen, egymást kiegészítve. Az interjúalanyok esetében „segítô én” kialakulásának feltétele a „felépülő én” megléte, a kialakult „önismeret” (ahogy ezt az interjúalanyok nevezik), de a legtöbb esetben mindkettố jelen van már a „terápia” (a rehabilitációs otthonban töltött idő) megkezdésekor, és helyzettôl függôen váltakozva kerül egyik vagy másik az előtérbe.

„Régen a „junkie” énemböl beszéltem, aztán volt egy ilyen ifjú titán szakember részem, aztán a diplomás szakember részem, aztán a családos ember is. Beépülnek ezek, ugye, mint rétegek" (Zénó).

Hangsúlyos az „önismeret” a segítő szerepben, mert ezzel az interjúalanyok a klienst helyezik a középpontba - hiszen kellő „önismerettel” már tudnak másra figyelni. A segítő feladata sok esetben a hallgatás, rávezetés. Ebben a szerepben a segítô a klienssel együtt újra végigjárja a felépülés útját, de ô már tovább lát. „Én a terápián végig magammal foglalkoztam, tehát nem azzal, hogy én ki leszek, vagy mi leszek, hogy most éppen ki vagyok, meg ki voltam, meg mi voltam, tehát a gyökereimmel...,de tulajdonképpen én az elsố pillanattól a segítố énemmel dolgoztam...” (Zénó); „és ott éreztem meg, hogy ez nekem jól esik, hogy jól esik a másikkal beszélgetni az ó apró problémájáról, és a saját tapasztalataimat odaadva valamelyest segíteni.” (Feri); „nekem ez egy titkos vágyam volt...., azt éreztem, hogy nekem ezt kell csinálni...” 
(Sindy); „jó érzés volt adni, ez az egyik... másik, hogy nagyon szerettem a X-t (intézményt), akkor is, és abszolút el tudtam magam képzelni" (Peti).

A segítô a beszélgetések során nem saját magára fókuszál, hanem tud a kliensre figyelni. Több beszámolóban megjelenik a segítésből eredô töltekezés is: „egyszer-egyszer tudnak olyat mondani, ami engem is megérint, és megsegít a saját dolgaim elaborálásában" (Feri). A „megsebzett gyógyító” címszó alatt is találkoztunk olyan idézetekkel, ahol a segítés és a tapasztalati segítô saját felépülési munkája összekapcsolódik.

A felépülô segítôk, tapasztalati szakértôk fontos és értékes tagjai tudnak lenni az addiktológiai kezelésnek, ezért is fontos olyan vizsgálatokat végezni, amely elôsegíti a sajátélményú szakemberek célzott helyének megtalálását (Kassai és mtsai, 2015).

\section{KÖVETKEZTETÉSEK}

Tanulmányunk célja annak bemutatása, hogyan használható az IPA az élmény és identitás vizsgálatára, továbbá miért lehetséges az IPA-t olyan kutatási területen alkalmazni, mint a szerhasználat és a felépülés. Az IPA a fenomenológiai kutatási hagyomány alkalmazható és könnyen hozzáférhetô módszere, amely kiemeli és részletesen elemzi az egyéni tapasztalatot. Az ilyen jellegú kutatás segítséget nyújthat az egészségügyi kezelésnek, hogy elérje, meghallja és megértse az egyén tapasztalatát, szükségletét. Továbbá az IPA nemcsak az ellátás fejlesztéséhez, de az elméletalkotáshoz is hozzá tud járulni, például a felépülés lehetôségeinek feltárásával pszichoaktív és új pszichoaktív szerhasználók esetében.

\section{IRODALOM}

Barros, F. A. (2013). An exploration of choice in heroin addiction: 'An interpretative phenomenological analysis of a small sample of people in recovery' (Doctoral dissertation, Middlesex University/New School of Psychotherapy and Counselling [NSPC]).

Gadamer, H. G. (1960). Igazság és módszer. Egy filozófiai hermeneutika vázlata. Budapest: Osiris

Gray, M. T. (2005). The shifting sands of self: a framework for the experience of self in addiction. Nursing Philosophy, 6(2), 119-130.

Hänninen, V., \& Koski-Jännes, A. (1999). Narratives of recovery from addictive behaviours. Addiction, 94(12), 1837-1848.

Hill, J. V., \& Leeming, D. (2014). Reconstructing 'the alcoholic': recovering from alcohol addiction and the stigma this entails. International Journal of Mental Health and Addiction, 12(6), $759-771$.

James W. (1890/1981). The Principles of Psychology, vols 1-2. Harvard University Press, Cambridge, MA.

Kassai S., Pintér J. N., \& Rácz J. (2015). Addiktológiai területen dolgozó tapasztalati szakértok: interpretatív fenomenológiai analízisen alapuló kutatás. Psychiatria Hungarica, 30(4), 372-388.

Kassai S., Kiss M., Pintér J. N., \& Rácz J. (2016). A hanghallás élménye és az önsegítố csoport szerepe - interpretatív fenomenológiai analízisen alapuló kutatás. Psychiatria Hungarica, 31(1), $52-70$. 
Kassai S., Pintér J. N., \& Rácz J. (2016). A szintetikus kannabinoid termék használat élménye: interpretatív fenomenológiai analízisen alapuló kutatás. Mentálhigiéné és Pszichoszomati$k a, 17(4), 297-322$.

Koski-Jännes, A. (1998). Turning points in addiction careers: five case studies. Journal of Substance Misuse, 3(4), 226-233.

Koskið]ännes, A. (2002). Social and personal identity projects in the recovery from addictive behaviours. Addiction Research and Theory, 10(2), 183-202.

Larkin, M., \& Griffiths, M. D. (2002). Experiences of addiction and recovery: The case for subjective accounts. Addiction Research, Theory, 10(3), 281-311.

Laudet, A. B. (2007). What does recovery mean to you? Lessons from the recovery experience for research and practice. Journal of substance abuse treatment, 33(3), 243-256.

Narancsik, G., \& Szummer, Cs. (2013): Closing the gap between phenomenological and naturalistic approaches in psychology and philosophy - perspectives for the new millennium. Daseinsanalyse. Yearbook for phenomenological anthropology and psychotherapy, 2013, 29, 97-103.

McIntosh, J., \& McKeganey, N. (2000). Addicts' narratives of recovery from drug use: constructing a non-addict identity. Social Science, Medicine, 50(10), 1501-1510.

McIntosh, J., \& McKeganey, N. (2001). Identity and recovery from dependent drug use: The addict's perspective. Drugs: Education, Prevention, and Policy, 8(1), 47-59.

Osborn, M., \& Smith, J. A. (2006). Living with a body separate from the self. The experience of the body in chronic benign low back pain: an interpretative phenomenological analysis. Scandinavian journal of caring sciences, 20(2), 216-222.

Pietkiewicz, I., \& Smith, J. A. (2014). A practical guide to using interpretative phenomenological analysis in qualitative research psychology. Psychological Journal, 20(1), 7-14.

Pintér J. N., Kassai S., \& Rácz J. (2016): Szintetikus kannabinoid termék használók identitásszervezôdésének vizsgálata interpretatív fenomenológiai analízissel. Psychiatria Hungarica, 31(4), 313-326.

Rácz J., Kassai S., \& Pintér J. N. (2016). Az interpretatív fenomenológiai analízis (IPA) mint kvalitatív pszichológiai eszköz bemutatása: Szakirodalmi összefoglalás. Magyar Pszichológiai Szemle, 71(2), 313-336.

Rácz, J., Pintér, J. N., Kassai, Sz. (2017). Az interpretatív fenomenológiai analízis elmélete, módszertana és alkalmazási területei. Budapest: L’Harmattan

Ricoeur, P. (1991), 'Narrative identity', Philosophy Today, 35, 73-81.

Rodriguez, L., \& Smith, J. A. (2014). 'Finding Your Own Place': An Interpretative Phenomenological Analysis of Young Men's Experience of Early Recovery from Addiction. International Journal of Mental Health and Addiction, 12(4), 477-490.

Shinebourne, P., \& Smith, J. A. (2009). Alcohol and the self: An interpretative phenomenological analysis of the experience of addiction and its impact on the sense of self and identity. $A d$ diction Research, Theory, 17(2), 152-167.

Shinebourne, P., \& Smith, J. A. (2011). Images of addiction and recovery: An interpretative phenomenological analysis of the experience of addiction and recovery as expressed in visual images. Drugs: education, prevention and policy, 18(5), 313-322.

Smith, J. A., \& Osborn, M. (2007): Interpretative phenomenoligical analysis. In J. A. Smith (Ed.), Qualitative Psychology: A Practical Guide to Research Methods. London: Sage, 53-80.

Smith, J. A. (2011). Evaluating the contribution of interpretative phenomenological analysis. Health psychology review, 5(1), 9-27.

Smith, J., Flowers, P., \& Larkin, M. (2009). Interpretative Phenoomological Analysis: theory, method and research. London: Sage.

Szummer Cs. (1993a). Freud nyelvjátéka. A pszichoanalizis mint hermeneutika és narráció. Budapest: Cserépfalvi - MTA Pszichológiai Intézet. 
Szummer Cs. (1993b). Hermeneutikai fordulat elôtt a pszichológia? Pszichológia, 13(4), 579.

Szummer Cs. (2011). A fenomenológia váratlan felbukkanása az ezredforduló megismerés-tudományában. Magyar Filozófiai Szemle, 2, 141-163.

Ullmann, T., \& Olay, C. (2011). Kontinentális filozófia a XX. században. Budapest: L’Harmattan.

Zahavi, D (2003). Husserl's phenomenology. California: Stanford University Press, Stanford.

\section{SUBSTANCE USE AND RECOVERY - EXAMINING EXPERIENCE AND IDENTITY WITH INTERPRETATIVE PHENOMENOLOGICAL ANALYSIS}

$$
\text { KASSAI, SZILVIA - PINTÉR, JUDIT NÓRA - RÁCZ, JÓZSEF }
$$

The aim of this study is to introduce how the method of Interpretative Phenomenological Analysis (IPA) is applicable to examine experiences and identity change during substance use and recovery. The method of IPA originates from the research area of health psychology, and most of the recent IPA studies are published in this area too. Because IPA is able to examine significant experiences that could influence the person's everyday life and the way he/she perceive his/her identity such as the experience of addiction and recovery. This study presents the process of an IPA study that could discover experiences of identity change. In this study we show why the experience and identity change of addiction and recovery is important to examine. In this study we also introduce relevant results of previous IPA research and our own research.

Keywords: interpretative phenomenological analysis, experience, identity, substance use, recovery 